Pak. j. sci. ind. res. Ser. A: phys. sci. 201457 (2) 86-94

\title{
Quality of Wastewater Used for Conventional Irrigation in the Vicinity of Lahore and its Impact on Receiving Soils and Vegetables
}

\author{
Farzana Bashir*, Muhammad Tariq, Rauf Ahmad Khan and Tahira Shafiq \\ CEPS, PCSIR Labs Complex, Lahore-54600, Pakistan
}

(received March 30, 2012; revised July 16, 2013; accepted August 5, 2013)

\begin{abstract}
The quality of wastewater was evaluated from Rohi Nullah, Lahore, Pakistan, for one year (2008-2009) from those points where it is used for irrigation of crops on both sides of Nullah. The quality of wastewater was evaluated for pollution load including $\mathrm{pH}$, sulphide, phenol, methylene blue active substances, chemical oxygen demand (COD), biochemical oxygen demand (BOD), irrigation quality (electric conductivity, total dissolved solids, total suspended solids, sodium adsorption ratio, residual sodium carbonate and chlorides) nutritional value (total nitrogen, total phosphorus and total potassium) and for metal concentration. The metals analysed were cadmium, nickel, chromium, zinc, manganese, cobalt and copper. With respect to pollution load BOD, COD and sulphide concentration was above the National Environmental Quality Standard (NEQS) limit. Nitrogen and phosphorus were contained at levels of concern in wastewater but the level of potassium was below crop requirements. The concentration of nickel, chromium, manganese and copper was above the FAO standards, while the concentration of cadmium, zinc and cobalt fell within FAO standards. Considering NEQS standards, the metals concentration was within limits. Temporal variations were prominent in some parameters and mostly higher values were observed in summer and lower in winter season. There was accumulation of heavy metals in soils receiving wastewater for irrigation. The metal contents in soils follow the order $\mathrm{Mn}>\mathrm{Co}>\mathrm{Zn}>\mathrm{Cr}>\mathrm{Ni}>\mathrm{Cu}>\mathrm{Cd}$. It was observed that the concentration of all studied toxic metals in edible part of the vegetables was above the critical level. Finally, it was concluded that the practice of using wastewater in irrigation for growing vegetables and other crops is non-sustainable.
\end{abstract}

Keywords: wastewater, irrigation quality, COD, BOD, SAR, metal ions

\section{Introduction}

Wastewater consists of the effluent discharged from household, industries, institutions and commercial buildings. It contains organic matter, some food nutrients and heavy metals. Growing crops with such water for longer periods may lead to accumulation of these toxic metals in soils and plants. The safe disposal of wastewater is a severe problem faced by large metropolitan areas like Karachi, Lahore etc., with limited space for land based treatment and disposal. Wastewater is also a resource and may increase the agricultural productivity due to its nutrient contents and irrigation with wastewater can lower the fertiliser requirements and also increase crop yields (Quinn, 1979).

Under arid and semiarid conditions the use of wastewater for irrigation is considered by far the best option because this practice not only minimizes the environmental pollution but also aids in expansion of irrigated agriculture. In our conditions the two most important factors limiting soil

*Author for correspondence; E-mail: beefarzana@yahoo.com productivity are water and organic matter, both substances as well as plant nutrients are supplied if wastewater is used on agricultural land. There are many studies indicating the beneficial effects of wastewater nutrients on plant growth ( Kipnis et al., 1979; Overman, 1978; Day and Tucker, 1977; Day et al., 1975). However, there are some hazards associated with the use of wastewater in irrigation. These are trace heavy metals, soluble salts and other organic and inorganic constituents that may be dangerous for plants causing phytotoxicity. Repeated application of wastewater can accumulate metals in soil and then ultimately be taken up by plants (Antonious et al., 2011; Magdaleno et al., 2011; Bigdeli and Seilsepor, 2008; Bashir et al., 2007; Abdel-Saheb et al., 1994; Wallace and Wallace, 1994). Salinity however, is presumably the most important single water quality factor which affects both soil and crop production.

Quality of wastewater when used for broad irrigation is of particular importance in our climatic conditions where, extremes of temperature and low relative humidity result in high rates of evaporation. It results 
in salt deposition from applied water which tends to accumulate in the soil profile. Physical and mechanical properties of the soil such as $\mathrm{pH}$, cation exchange capacity, dispersion of particles and soil structure are very sensitive. Thus, when wastewater reuse is planned, its composition and impact on receiving soils must be taken into consideration. The present study was therefore, designed to determine temporal variations on the pollution load, irrigation quality, nutrient value and metal concentration of wastewater. The other objective was to study the impact of untreated wastewater irrigation on soil and to evaluate the uptake of heavy metals by vegetables and fodder under the effect of application of wastewater.

\section{Materials and Methods}

Study area. Rohi Nullah, is the storm water drain in the vicinity of Lahore. Industrial and domestic wastewater dumping has turned it into a perennial drain. There are approximately 120 industries of different nature situated along this Nullah. The major are textile, food, electroplating, paper, tanneries, and polymer production etc. Almost all industries discharge their untreated effluent into it. In addition domestic sewage of some parts of the city and of other villages also enters into it.

There are agricultural lands on both sides of the Nullah and the farmers of that area are pumping out the wastewater and using it for irrigating their field for growing vegetables and fodders.

Sampling procedures and analysis. The wastewater samples from Rohi Nullah were periodically collected on monthly bases for one year (2008-2009) from a site, where, it is used directly for surface irrigation. The grab method was used for sample collection. Each sample consisted of four sub-samples, preserved accordingly (APHA, 2005) and placed in 1 litre polyethylene containers. Temperature, $\mathrm{pH}$ and electric conductivity (EC) were measured in the field, while, other chemical properties of wastewater were measured by using standard methods (APHA, 2005). The concentration of metals ( $\mathrm{Cd}, \mathrm{Co}, \mathrm{Cr}, \mathrm{Cu}, \mathrm{Mn}, \mathrm{Ni}$ and $\mathrm{Zn}$ ) was determined by AAS (Model Varian Spectr AA - 40).

Composite surface soil samples $(0-15 \mathrm{~cm})$ were collected from two sites which were irrigated partially or completely with wastewater of Rohi Nullah. At site I, 6 agricultural fields were selected that had previously been irrigated with tube-well water but currently are under partial wastewater irrigation and considered as control soil (CS) because in that area there is no agricultural field that is not irrigated by wastewater. From site II, 24 agricultural fields were randomly selected that had been irrigated with Rohi Nullah wastewater from 35 years or longer (WWS). From CS, fodder (Zea mays) sample was collected, while, from WWS vegetable samples (spinach, bitter gourd, chili and gourd) were collected. The samples were placed in labeled poly-ethylene bags and transported to the laboratory. Soil samples were air-dried under shade, ground and sieved through $2 \mathrm{~mm}$ sieve and stored in plastic jar, for further analysis. Samples were analysed for $\mathrm{pH}, \mathrm{EC}, \mathrm{SAR}$ and cation exchange capacity (CEC) following methods described by US Salinity Staff (Richards, 1954), texture by hydrometric method and organic matter by Walky-Blake method of US Salinity Lab Staff, (Richards, 1954). The soil was digested by using method described by Tessier et al. (1979) and concentration of total metals were determined by AAS (Model Varian, Spectr AA-40).

Vegetables viz. spinach (Spinacia oleracea), bitter gourd (Momordica charantia), chili (Capsicum annum) and gourd (Lagenaria vulgarius) from site WWS and maize (Zea mays) were collected from site CS. The plant materials was digested according to AOAC (2005) methods and analysed for metals (Cd, Ni, Cr, Zn, Mn, $\mathrm{Co}$ and $\mathrm{Cu}$ ) by AAS (Model Varian Spectr AA-40).

\section{Results and Discussion}

Quality of wastewater. The quality of wastewater was evaluated for pollution load, irrigation quality, nutritional value and metal ion concentration and is described in Table 1 .

Pollution load of waster water. Temperature, $\mathrm{pH}$, sulphide, phenol, $M B A S, C O D, B O D$. During the study period, the temperature varied for different sampling dates at sampling points. The average value of temperature was $26.86 \pm 7.44{ }^{\circ} \mathrm{C}$ (Table 1) ranging from lower values during winter and higher in the summer (Fig. 1). The average value of $\mathrm{pH}$ was 7.81 \pm 0.29 . According to National Environmental Quality Standards (NEQS) as described by Pakistan Environmental Protection Act (PEPA, 1997), the permissible limits for temperature and $\mathrm{pH}$ are $40{ }^{\circ} \mathrm{C}$ and 6-10, respectively. The analysed wastewater has $\mathrm{pH}$ and temperature within NEQS limits.

The average concentration of sulphide was $8.12 \pm 2.33$ $\mathrm{mg} / \mathrm{L}$. Sulphide is produced in wastewater naturally 
Table 1. Pollution load, irrigation quality, nutrient value and metal ion concentration of wastewater of Rohi Nullah used for irrigation during 2008-2009

\begin{tabular}{|c|c|c|c|c|c|c|c|c|}
\hline \multicolumn{2}{|l|}{ Parameter } & $\begin{array}{l}\text { Temperature } \\
\left({ }^{\circ} \mathrm{C}\right)\end{array}$ & $\mathrm{pH}$ & $\begin{array}{l}\text { Sulphide } \\
\text { (mg/L) }\end{array}$ & $\begin{array}{l}\text { Phenol } \\
(\mathrm{mg} / \mathrm{L})\end{array}$ & $\begin{array}{l}\text { Methylene } \\
\text { blue active } \\
\text { substances } \\
(\mathrm{mg} / \mathrm{L})\end{array}$ & $\begin{array}{l}\text { Chemical } \\
\text { oxygen } \\
\text { demand } \\
(\mathrm{mg} / \mathrm{L})\end{array}$ & $\begin{array}{l}\text { Biochemical } \\
\text { oxygen } \\
\text { demand } \\
(\mathrm{mg} / \mathrm{L})\end{array}$ \\
\hline \multicolumn{2}{|c|}{$\begin{array}{l}\text { Average } \pm \text { SD } \\
\text { National Environmental } \\
\text { Quality Standard }\end{array}$} & $\begin{array}{l}26.86 \pm 7.44 \\
40^{\circ} \mathrm{C}\end{array}$ & $\begin{array}{l}7.81 \pm 0.29 \\
6-10\end{array}$ & $\begin{array}{l}8.12 \pm 2.33 \\
1.0\end{array}$ & $\begin{array}{l}0.09 \pm 0.03 \\
0.1\end{array}$ & $\begin{array}{l}3.23 \pm 1.30 \\
10\end{array}$ & $\begin{array}{l}476.4 \pm 99.2 \\
150\end{array}$ & $\begin{array}{l}179.0 \pm 44.9 \\
80\end{array}$ \\
\hline \multicolumn{2}{|l|}{ Parameter } & $\mathrm{pH}$ & $\begin{array}{l}\text { Electric } \\
\text { conductivity } \\
(\mathrm{dS} / \mathrm{m})\end{array}$ & $\begin{array}{l}\text { Total } \\
\text { dissolved } \\
\text { solids } \\
(\mathrm{mg} / \mathrm{L})\end{array}$ & $\begin{array}{l}\text { Total } \\
\text { suspended } \\
\text { solids } \\
(\mathrm{mg} / \mathrm{L})\end{array}$ & $\begin{array}{l}\text { Sodium } \\
\text { adsorption } \\
\text { ratio }\end{array}$ & $\begin{array}{l}\text { Residual } \\
\text { sodium } \\
\text { carbonate }\end{array}$ & $\begin{array}{l}\text { Chlorides } \\
(\mathrm{mg} / \mathrm{L})\end{array}$ \\
\hline \multicolumn{2}{|c|}{$\begin{array}{ll}\text { Average } \pm \text { SD } & \\
\text { FAO } & \text { None } \\
\text { (degree of } & \text { slight to } \\
\text { restriction } & \text { moderate } \\
\text { on use) } & \text { severe }\end{array}$} & $\begin{array}{l}6.5-8.4 \\
-\end{array}$ & $\begin{array}{l}1.147 \pm 0.258 \\
<0.7 \\
0.7-3.0 \\
>3.0\end{array}$ & $\begin{array}{l}917 \pm 198 \\
<450 \\
450-2000 \\
>2000\end{array}$ & $92.8 \pm 20.6$ & $\begin{array}{l}5.44 \pm 0.76 \\
<3 \\
3-9 \\
>9\end{array}$ & $\begin{array}{l}2.19 \pm 0.58 \\
<1.25 \\
1.25-2.5 \\
>2.5\end{array}$ & $\begin{array}{l}4.08 \pm 0.95 \\
<4 \\
4-10 \\
>10\end{array}$ \\
\hline \multicolumn{2}{|l|}{ Parameter } & $\begin{array}{l}\text { Cadmium } \\
(\mathrm{mg} / \mathrm{L})\end{array}$ & $\begin{array}{l}\text { Nickel } \\
(\mathrm{mg} / \mathrm{L})\end{array}$ & $\begin{array}{l}\text { Chromium } \\
(\mathrm{mg} / \mathrm{L})\end{array}$ & $\begin{array}{l}\text { Zinc } \\
(\mathrm{mg} / \mathrm{L})\end{array}$ & $\begin{array}{l}\text { Manganese } \\
(\mathrm{mg} / \mathrm{L})\end{array}$ & $\begin{array}{l}\text { Cobalt } \\
(\mathrm{mg} / \mathrm{L})\end{array}$ & $\begin{array}{l}\text { Copper } \\
(\mathrm{mg} / \mathrm{L})\end{array}$ \\
\hline \multicolumn{2}{|c|}{$\begin{array}{l}\text { Average } \pm \mathrm{SD} \\
\text { FAO standard }(\mathrm{mg} / \mathrm{L})\end{array}$} & $\begin{array}{l}0.01 \pm 0.003 \\
0.01\end{array}$ & $\begin{array}{l}0.42 \pm 0.36 \\
0.2\end{array}$ & $\begin{array}{l}0.21 \pm 0.05 \\
0.1\end{array}$ & $\begin{array}{l}0.78 \pm 0.21 \\
2.0\end{array}$ & $\begin{array}{l}0.17 \pm 0.03 \\
0.2\end{array}$ & $\begin{array}{l}0.02 \pm 0.003 \\
0.05\end{array}$ & $\begin{array}{l}0.37 \pm 0.12 \\
0.2\end{array}$ \\
\hline \multicolumn{2}{|l|}{ Parameter } & $\begin{array}{l}\text { Total } \\
\text { nitrogen }\end{array}$ & $\begin{array}{l}\text { Total } \\
\text { phosphorus }\end{array}$ & $\begin{array}{l}\text { Total } \\
\text { potassium }\end{array}$ & - & - & - & - \\
\hline \multicolumn{2}{|c|}{ Average \pm SD } & $38.97 \pm 9.6$ & $8.96 \pm 2.83$ & $27.25 \pm 9.81$ & - & - & - & - \\
\hline
\end{tabular}

and also as a result of human activities and causes offensive odours. Natural sources include non-specific and anaerobic bacterial reduction of sulphates and sulphur containing organic compounds. The permissible limit is $1.0 \mathrm{mg} / \mathrm{L}$ and all samples had sulphide concentration above the limit. Offensive odours can be harmful in many ways such as (i) reduction in appetite for food (ii) lowering in water consumption (iii) impaired respiration, nausea and vomiting and (iv) cause for mental perturbation.

Phenol is a by product in the biosynthesis of carbohydrates. It is also present in wastewater of iron and steel industry, organic chemical industry, photochemical and plastic industry. The average concentration of phenol in wastewater samples was $0.09 \pm .03 \mathrm{mg} / \mathrm{L}$ and was within NEQS limit of $0.1 \mathrm{mg} / \mathrm{L}$.

Detergents are used in many industries and in everyday life. They affect aquatic environments by causing foaming, limiting oxygen production and causing eutrophication. Anionic detergents are also called MBAS (methylene blue active substances) due to their method of detection in wastewater. In this study, the average value was $3.23 \pm 1.30 \mathrm{mg} / \mathrm{L}$. The NEQS limit for detergent is $10 \mathrm{mg} / \mathrm{L}$ and all the samples fell within permissible limits. This is due to the fact that the anionic detergents used are biodegradable in the environment.

The concentration of organic matter could be measured by $\mathrm{BOD}_{5}$, while $\mathrm{COD}$ is the measure of the total quantity of oxygen required to oxidise all organic matter into $\mathrm{CO}_{2}$ and $\mathrm{H}_{2} \mathrm{O}$. The average results of $\mathrm{BOD}_{5}$ and $\mathrm{COD}$ are presented in Table 1. Low $\mathrm{BOD}_{5}$ is an indicator of less polluted water, while high $\mathrm{BOD}_{5}$ indicates polluted water. When sewage is applied to the soil it tends to affect status of oxygen in the soil in two ways, first directly by which the oxygen in the soil pores is consumed by microorganisms for the decomposition of organic matter added through wastewater. Secondly indirectly, the fine organic matter in sewage adversely affects soil porosity. This gradually reduces the capacity of the soil to exchange air and as a consequence of which the oxygen status of the soil is lowered as described by Mohan (1989). According to NEQS the permissible limit for $\mathrm{BOD}_{5}$ is $80 \mathrm{mg} / \mathrm{L}$ and for $\mathrm{COD}$ is $150 \mathrm{mg} / \mathrm{L}$. In the studied samples the average concentration of $\mathrm{BOD}_{5}$ and COD was $179.0 \pm 44.9$ and $476.4 \pm 99.2$ $\mathrm{mg} / \mathrm{L}$, respectively. The reason for high COD and $\mathrm{BOD}_{5}$ may be due to the presence of a large number of industries that discharge their untreated effluents into 
the drain. The high values of $\mathrm{COD}$ and $\mathrm{BOD}_{5}$ are in agreement with other studies as described by literature (Kamel and Nada, 2008; Rahmani, 2007).

Temporal variations in wastewater temperature, $\mathrm{pH}$, sulphide, phenol, MBAS, COD and $\mathrm{BOD}_{5}$ are shown in Fig.1. As expected lower values of temperature observed in winter and high in summer. No temporal variations were observed with respect to effluent $\mathrm{pH}$ and MBAS. Sulphide concentration remained high during winter and declined in summer which may be due to high temperature and heavy rains during this period. The dilution factor of monsoon rain was also observed in case of COD and BOD because lower values of COD and BOD were observed during summer and higher in winter. The presence of phenol shows an inconsistent patron during the whole year and did not show any particular trend about its presence or absence.

Irrigation quality. $p H, E C, T D S, T S S, S A R, R S C$, Chlorides. Traditionally, irrigation water is grouped into various quality classes that provide a rough indication of potential adverse affects on crop growth. According to FAO guidelines as described by Pescod (1992), the validity of irrigation water has three degrees of severity (i) none (ii) slight to moderate and (iii) severe as described in Table 1. Values shown are applicable

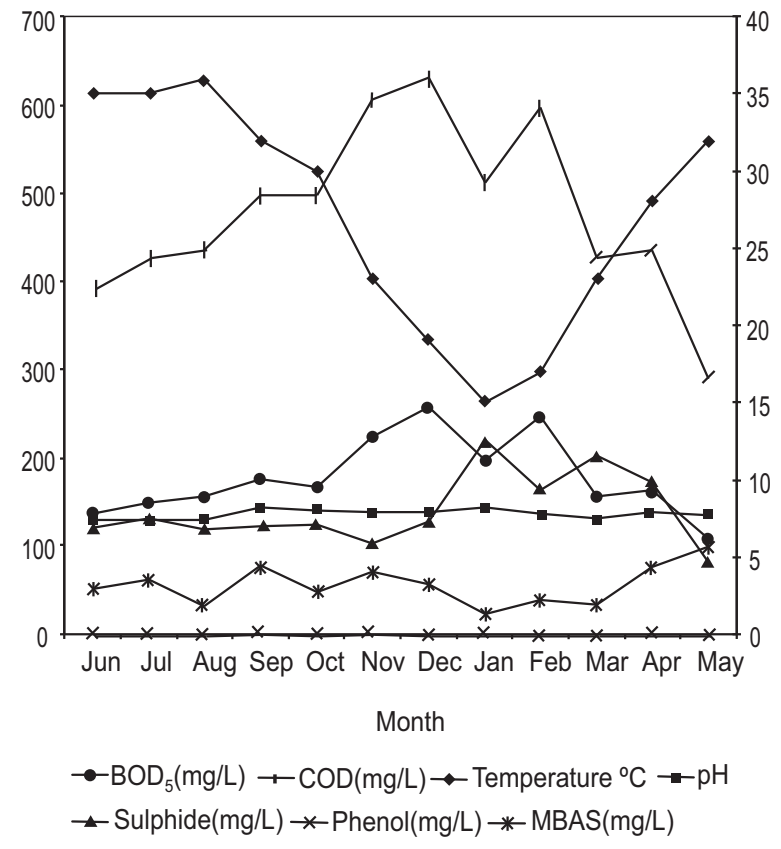

Fig. 1. Temporal variations in pollution load of wastewater at Rohi Nullah during 20082009. under normal field conditions prevailing in most irrigated areas in the arid and semiarid regions of the world.

As described by Richard (1954), the characteristics of irrigation water that appear to be most important in determining its quality are (1) total concentration of soluble salts; (2) relative proportion of sodium to other cations and (3) concentration of other elements that may be toxic like heavy metals.

The average $\mathrm{pH}$ in studied wastewater samples was 7.81 that lies within normal range. Concentration of total dissolved solids (TDS) and electric conductivity (EC) are important characteristics of water that determines its quality. The average values of EC and TDS was $1.147 \mathrm{dS} / \mathrm{m}$ and $917.93 \mathrm{mg} / \mathrm{L}$, respectively. According to FAO guidelines these results fall in the category, where degree of restriction on use is slight to moderate.

At low concentrations chloride content of water for surface irrigation should be in the range of $4-10 \mathrm{mg} / \mathrm{L}$ and high concentration creates problem and is harmful for crops. In wastewater of Rohi Nullah the average concentration of chlorides was $4.06 \mathrm{mg} / \mathrm{L}$ that falls within normal range of FAO standard .

The sodium adsorption ratio (SAR) is a useful index for designing the sodium hazard of water used for irrigation. The critical value for SAR is $>9.0$. Above this range there is danger of sodium hazard. The average value of SAR was 5.44 that lies in the second category of FAO i.e., restriction on use was slight to moderate. With respect to residual sodium carbonate (RSC) the values also lies within normal range.

Temporal variations in irrigation quality of wastewater are presented in Fig. 2 and 3. With respect to EC, TDS and TSS higher values were observed in winter and less in summer, which may be due to heavy monsoon in summer. The trend for SAR, RSC and chlorides is more or less similar to EC over this period.

Nutrient values. Total nitrogen, Total phosphorus, potassium. Wastewater contains nutrients in a variety of chemical forms with seasonal variation in concentration. The average concentrations of total nitrogen, total phosphorus and potassium were 38.97, 8.96 and 27.25, respectively, as described in Table 1 . Total nitrogen in water is formed by combination of ammonia nitrogen, organic nitrogen, nitrate nitrogen and nitrite nitrogen. Nitrogen and phosphorus were contained at levels of concern in wastewater but the level of potassium was 


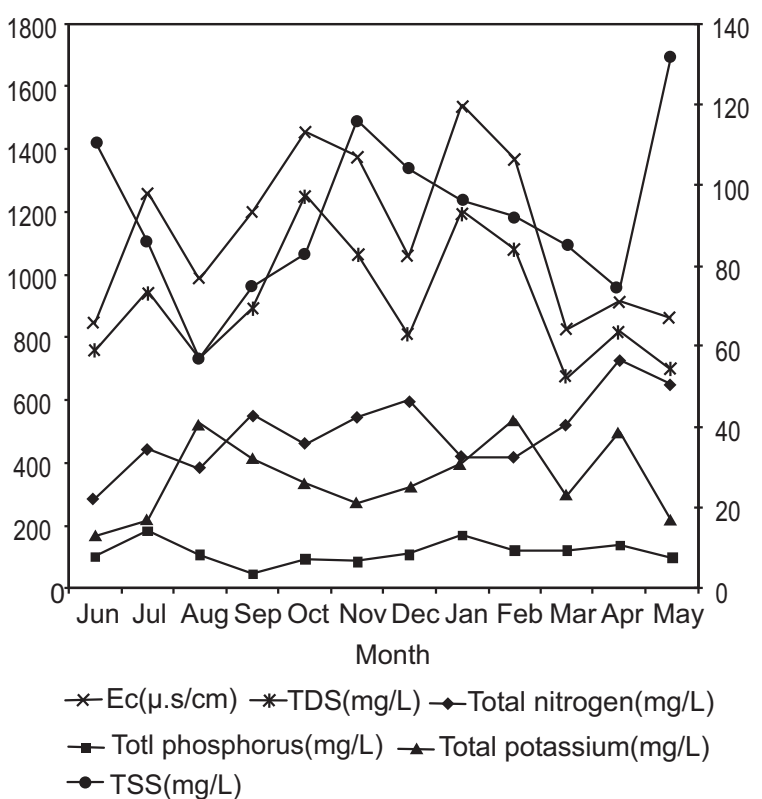

Fig. 2. Temporal variations in irrigation quality and nutrient value of wastewater at Rohi Nullah during 2008-2009.

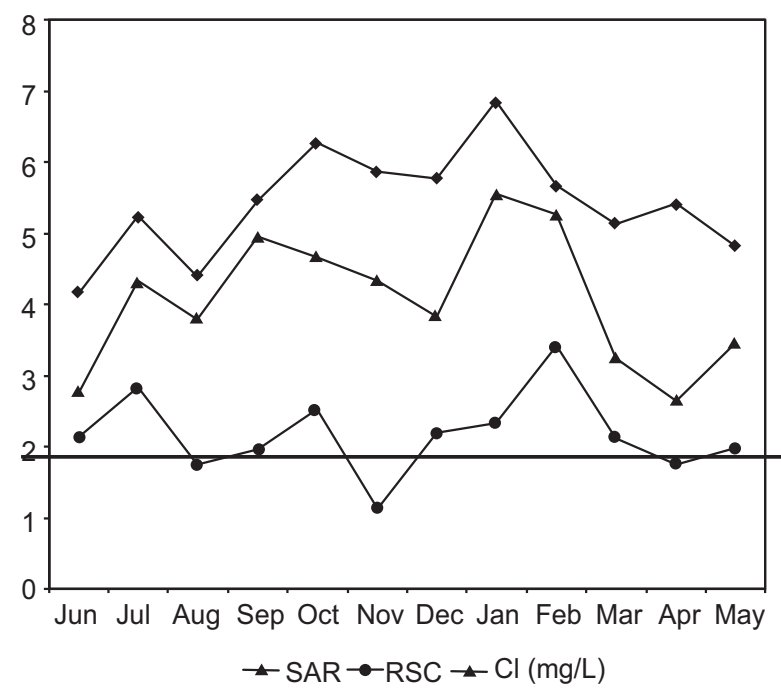

Fig. 3. Temporal variations in irrigation quality of wastewater at Rohi Nullah during 2008-2009. below crop requirement. Such findings are also available in literature as reported by Feigin et al. (1991). Temporal changes in wastewater nutrient values are shown in Fig.3. The prominent variations were observed with respect to total nitrogen and potassium i.e., higher values in winter and lower in summer, while total phosphorus showed not prominent variations.

Metal ions. The concentration of metal ions is presented in Table 1. The concentrations of nickel, chromium, manganese and copper were above the FAO standards, while the concentration of cadmium, zinc and cobalt fell within FAO standards. Considering NEQS standards, the metals concentration was within limits. The high concentration of nickel, chromium, manganese and copper may be due to the effluents of leather industry, and other cottage industry, but especially the electroplating industry that discharges their untreated wastewater into drain.

The comparison of heavy metal concentration in untreated wastewater from the data of Pakistan and other countries suggested that the values were higher than the level observed by van der Hoek et al. (2002) but in comparison with Rai and Tripathi (2007) investigated in industrial wastewater in Lotha village.

Gupta et al. (1986) has indicated that the concentration of heavy metals in wastewater varied depending upon the type of industry these effluents come from. They reported that effluents from industries manufacturing sewing machines, bicycles and their spare parts contained higher concentration of pollutant elements compared to those from textile, woolen, and dairy industries.

Temporal variations in metal ion concentration showed (Fig.4) inconsistent information about the presence of heavy metals in wastewater.

Impacts of wastewater irrigation on soil and crops. The texture of the soils studied was silt loam and loam. The average values of $\mathrm{pH}$ of WWS were slightly lower as compared to soil of CS (Table 2). Production of organic

Table 2. Some physicochemical properties of sewage irrigated soils collected from WWS and CS site

\begin{tabular}{|c|c|c|c|c|c|}
\hline \multirow[t]{2}{*}{ Parameter } & \multicolumn{4}{|c|}{ Wastewater irrigated soils } & \multirow{2}{*}{$\begin{array}{l}\text { Control soil } \\
\text { Maize }\end{array}$} \\
\hline & Spinach & Bittergourd & Chilli & Gourd & \\
\hline $\mathrm{pH}$ & $7.75 \pm 0.22$ & $7.86 \pm 0.33$ & $7.86 \pm 0.22$ & $7.92 \pm 0.09$ & $8.30 \pm 0.33$ \\
\hline Sodium adsorption ratio & $10.53 \pm 1.06$ & $10.67 \pm 1.14$ & $10.58 \pm 1.38$ & $11.81 \pm 1.32$ & $8.38 \pm 0.73$ \\
\hline $\begin{array}{l}\text { Cation exchange capacity } \\
(\mathrm{cmol} / \mathrm{kg})\end{array}$ & $8.60 \pm 0.62$ & $7.79 \pm 0.70$ & $7.43 \pm 0.58$ & $7.65 \pm 0.90$ & $5.38 \pm 0.48$ \\
\hline Organic matter (\%) & $1.10 \pm 0.21$ & $1.06 \pm 0.21$ & $1.06 \pm 0.13$ & $1.13 \pm 0.45$ & $0.82 \pm 0.13$ \\
\hline Electric conductivity $(\mathrm{dS} / \mathrm{m})$ & $2.30 \pm 0.30$ & $2.27 \pm 0.43$ & $2.55 \pm 0.31$ & $2.15 \pm 0.64$ & $1.73 \pm 0.38$ \\
\hline
\end{tabular}




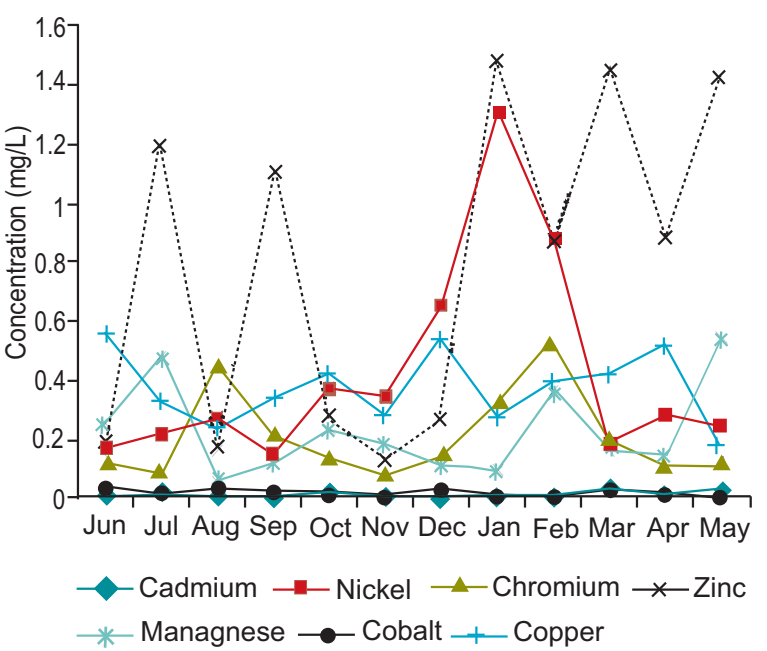

Fig. 4. Temporal variations in metal ion concentration of wastewater at Rohi Nullah during 20082009.

acids due to decomposition of organic matter may be the cause of lowering the $\mathrm{pH}$ of the soils irrigated with wastewater. The values of SAR, CEC, organic matter and electric conductivity of WWS were higher as compared to CS as described in Table 2. The increase in EC, SAR at WWS could be attributed to the addition of considerable quantities of dissolved salts through effluent. The addition of organic matter from sewage waste water rich in nutrients having high BOD resulted in increase of organic matter. These findings are similar to those of Murtaza et al. (2003) who observed below 15 the SAR value of city effluents irrigated soils. The increase in CEC in wastewater irrigated soils may be due to the increase in clay contents due to wastewater irrigation.

Repeated application of effluents could accumulate metals into soil because soil is an important sink for heavy metals due to its high retention capacities (Nolan et al., 2003). Transfer of heavy metals from water to soil and subsequently uptake and accumulation in edible part of vegetative tissue from soil represent a direct pathway for incorporation of heavy metals into human food chain (Liang et al., 2011).

Cadmium. The concentration of total cadmium in WWS and CS studied soils ranged from 4.2 to 12.7 and 1.20-2.30 (Table 3) with an average value of 9.35 and $1.72 \mathrm{mg} / \mathrm{kg}$, respectively, while the permissible limit is $0.5 \mathrm{mg} / \mathrm{kg}$ (Rowell, 1994). Generally, above $0.5 \mathrm{mg} / \mathrm{kg}$ for total cadmium in soil is considered evidence of soil contamination. As compared with the soils of CS the concentration of cadmium was very high in soils of WWC, which may be due to long irrigation practice with untreated wastewater that contain cadmium above the critical level (Table 3).

The concentration of cadmium in edible part of vegetables i.e., spinach (leaves), bitter gourd, chili, gourd (fruit) at WWS site ranged from 0.78 to 2.30 with an average value of $1.46 \mathrm{mg} / \mathrm{kg}$ (Fig. 5). While the concentration of $\mathrm{Cd}$ in maize (maize of the said area is

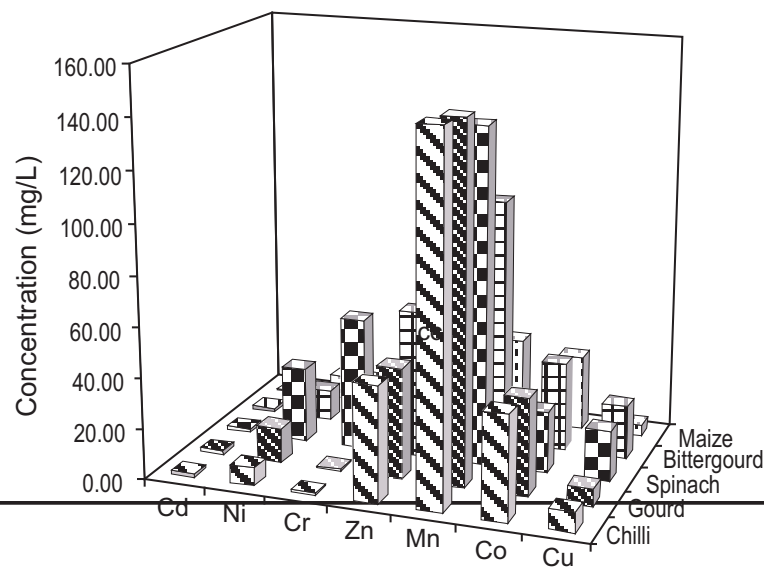

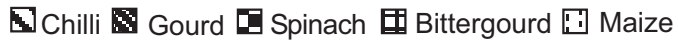

Fig. 5. Metal ions concentration $(\mathrm{mg} / \mathrm{L})$ in vegetables collected from wastewater irrigated fields.

Table 3. Metal concentration in wastewater irrigated (WWS) and in the control soil (CS)

\begin{tabular}{|c|c|c|c|c|c|c|c|}
\hline \multirow{2}{*}{$\begin{array}{l}\text { Parameter } \\
(\mathrm{mg} / \mathrm{kg})\end{array}$} & \multicolumn{3}{|c|}{ WWS soil } & \multicolumn{3}{|c|}{ CS soil } & \multirow[b]{2}{*}{ Permissible } \\
\hline & Max. & Min. & Average & Max. & Min. & Average & \\
\hline Cadmium & 12.7 & 4.2 & 9.3 & 2.30 & 1.20 & 1.72 & 0.5 \\
\hline Nickel & 63.45 & 31.6 & 43.1 & 49.20 & 32.0 & 39.50 & 25.0 \\
\hline Chromium & 76.0 & 43.2 & 61.7 & 48.80 & 28.50 & 37.62 & 200 \\
\hline Zinc & 180 & 48.58 & 85.1 & 112.0 & 64.00 & 90.0 & 80 \\
\hline Managnese & 476 & 230 & 347.7 & 319.0 & 150.0 & 243.3 & 900 \\
\hline Cobalt & 117.5 & 59.2 & 88.6 & 45.20 & 34.0 & 38.93 & 20 \\
\hline Copper & 48.5 & 12.7 & 32.4 & 21.60 & 15.20 & 18.20 & 20 \\
\hline
\end{tabular}


used as fodder i.e., whole plant without roots) collected from CS site ranged between 0.03-0.24 with average value $0.11 \mathrm{mg} / \mathrm{kg}$. The uptake of cadmium at contaminated site (WWS) was much greater than at CS. In fruit of all the vegetables and spinach leaves (i.e., edible parts), Cd was above the critical level of $0.01 \mathrm{mg} / \mathrm{kg}$ (WHO, 1996). Boon and Soltanpour (1992) observed maximum concentration of $\mathrm{Cd}$ in leaves of lettuce, cabbage and broccoli. Jaffer and Saleem (1987) also found higher $\mathrm{Cd}(>0.01)$ in radish, carrot, beans and spinach collected from Punjab, KPK and Azad Kashmir areas of Pakistan. Din et al. (2001) also found Cd concentration ranging from 0.10 to $1.58 \mathrm{ppm}$ in various vegetable samples collected from some industrial area of Punjab.

Cadmium is one of the most toxic elements with reported carcinogenic effects in humans. It accumulates mainly in the kidney and liver. It induces cell injury and death by interfering with calcium $(\mathrm{Ca})$ regulation in biological systems. It also causes bones to become brittle.

Nickel.Total nickel contents in soils ranged from 31.6 to 63.45 with average value of $43.1 \mathrm{mg} / \mathrm{kg}$ (Table 3). All studied soils of WWS contained total nickel above the permissible limit of $25 \mathrm{mg} / \mathrm{kg}$ (Rowell, 1994). Total concentration of nickel in soils that are partially irrigated with wastewater from few years ranged from 32.049.20 (Table 3) with an average value of $39.50 \mathrm{mg} / \mathrm{kg}$.

The concentration of Ni ranged from 5.86 to 36.45 $\mathrm{mg} / \mathrm{kg}$ in all vegetables collected from WWS. Maximum uptake $(29.74 \mathrm{mg} / \mathrm{kg}$ ) of $\mathrm{Ni}$ was by leaves (spinach), while uptake by fruits was lower i.e., 7.28, 13.85 and 11.9 for chili, gourd, and bitter gourd, respectively (Fig. 5). The average Ni concentration in maize from CS was $9.73 \mathrm{mg} / \mathrm{kg}$ and was within permissible limits of $10 \mathrm{mg} / \mathrm{kg}$ for food items by WHO (1996). The concentration of $\mathrm{Ni}$ in chilli at WWS was within limit, while for spinach, gourd and bitter gourd was above the limit. Jaffar and Saleem (1987) found Ni concentration $<1 \mathrm{mg} / \mathrm{kg}$ radish, onion, carrot, beans and spinach samples collected from the Punjab, KPK and Kashmir region of Pakistan. Sinha et al. (2005) also found higher concentrations of $\mathrm{Ni}$ in edible parts of vegetables that received river water for irrigation.

Chromium. In this study, total concentration of chromium ranged from 43.2 to $76.0 \mathrm{mg} / \mathrm{kg}$ with average value of $61.7 \mathrm{mg} / \mathrm{kg}$ (Table 3) in soils of WWS and ranged between $28.50-48.80 \mathrm{mg} / \mathrm{kg}$ with average value of $37.62 \mathrm{mg} / \mathrm{kg}$ in soils at CS. The chromium concen-tration was below the hazardous level of $200 \mathrm{mg} / \mathrm{kg}$ as reported by standard value by Huamain et al. (1999).

The uptake of $\mathrm{Cr}$ was maximum $(52.65 \mathrm{mg} / \mathrm{kg})$ by spinach leaves (Fig. 5) followed by bitter gourd with an average value of $18.98 \mathrm{mg} / \mathrm{kg}$, while the uptake was very low by chilli and gourd at WWS. At CS the maize had chromium concentrations ranged from 0.00 to 0.16 $\mathrm{mg} / \mathrm{kg}$ with average value of $0.10 \mathrm{mg} / \mathrm{kg}$. The spinach and bitter gourd contained $\mathrm{Cr}$ above the permissible limit of $1.3 \mathrm{mg} / \mathrm{kg}$ recommended for food by WHO (1996). In general, leaves accumulated more $\mathrm{Cr}$ than the respective fruits. These results are in agreement with that of Din et al. (2001), who found 1.21-64.80 ppm of $\mathrm{Cr}$ in effluent irrigated vegetables.

Zinc. Zinc is a heavy metal of much interest since it is a plant micronutrient as well as potential contaminant in soils. Total zinc concentration (Table 3 ) in soils under different vegetables (WWS) ranged from 48.58 to $180 \mathrm{mg} / \mathrm{kg}$ the permissible limit in soil is $80 \mathrm{mg} / \mathrm{kg}$ (Rowell, 1994).

The concentration of $\mathrm{Zn}$ varied from 32.53 to 75.50 $\mathrm{mg} / \mathrm{kg}$ in vegetables of WWS (Fig. 5). Maximum zinc was observed $(58.52 \mathrm{mg} / \mathrm{kg})$ in spinach leaves. The average uptake of zinc by maize collected from CS was 32.77. Zinc concentration in all samples studied from both sites was above the permissible limit of $5.0 \mathrm{mg} / \mathrm{kg}$ (WHO, 1996).

Manganese. Total manganese contents in soils under investigation ranged from 230 to 476 and 150 to 319 with average value of $347.7 \mathrm{mg} / \mathrm{kg}$ (Table 3 ). All the soils have Mn concentration within limits (400-900 $\mathrm{mg} / \mathrm{kg}$ ). The mean concentration (Fig. 5) of Mn in chilli, gourd, spinach and bitter gourd collected from farmer fields of WWS site was 144.22, 142.15, 133.98 and $98.62 \mathrm{mg} / \mathrm{kg}$, respectively. The uptake of $\mathrm{Mn}$ in chili, gourd and spinach was greater as compared to bitter gourd. The mean concentration of $\mathrm{Mn}$ in maize from CS was $34.45 \mathrm{mg} / \mathrm{kg}$ and varied from $18-48 \mathrm{mg} / \mathrm{kg}$. In all vegetables (edible portion) and fodder, Mn concentration was above the critical level of $6.61 \mathrm{mg} / \mathrm{kg}$ suggested by WHO (1996).

Cobalt. Total cobalt concentration (Table 3) in soils studied ranged from 59.2 to 117.5 with an average value of $88.63 \mathrm{mg} / \mathrm{kg}$ in soils of WWS and 34-45.20 with average value of $38.93 \mathrm{mg} / \mathrm{kg}$ in studied soils of CS. All the soils have cobalt concentration above the critical level of $20.0 \mathrm{mg} / \mathrm{kg}$. 
The Co concentration in vegetables (Fig. 5) and fodder ranged from 19.60 to 54.20 with mean value of 35.05 and 25.86 to 35.0 with mean value of $30.2 \mathrm{mg} / \mathrm{kg}$, respectively. The uptake of cobalt by spinach was less as compared to bitter gourd, chilli, gourd and maize.

Copper. Total copper concentration in WWS and CS soils under investigation ranged from $12.7-48.5 \mathrm{mg} / \mathrm{kg}$ (Table 3) with an average value of 32.40 , and 15.20 21.60 with average value of 18.20 , respectively. All the studied soil samples of WWS total $\mathrm{Cu}$ concentration was found above $20.0 \mathrm{mg} / \mathrm{kg}$, which is permissible limit as reported by Rowell (1994). While, the concentrations was within limit in partially irrigated soils of CS.

Copper concentrations (Fig.5) ranged from 5.87 to 29.10 $\mathrm{mg} / \mathrm{kg}$ in vegetable samples. While, in maize $\mathrm{Cu}$ concentration varied from 3.98 to $5.54 \mathrm{mg} / \mathrm{kg}$. In chilli and gourd the $\mathrm{Cu}$ concentration was within limit, while, the spinach and bitter gourd contained $\mathrm{Cu}$ above the permissible limit of the $10.0 \mathrm{mg} / \mathrm{kg}$, recommended byWHO (1996) for food items.

\section{Conclusion}

The metals presence in wastewater is contributed from a number of sources, like electroplating, batteries, pigments, metal coatings, plastics etc. The presence of these industries at Rohi Nullah makes the possibility of accumulation of metals in effluent irrigated soils. Metals are non-degradable and when present in sufficient quantities, pose the most serious environmental threat. Many countries have legislation that prohibits the cultivation of vegetables, with untreated wastewater but allows other non edible crops like cotton and timber. An example is Mexico, a country that make extensive use of wastewater in agriculture.

In many countries including Pakistan, farmers consider wastewater a valuable resource because of its high productivity. The municipalities are aware of the value of wastewater and sell it to farmers. The practice could be good in areas where there is no industrialization but in the case of big cities like Lahore, the environmental risks of wastewater irrigation are prominent. These are the industries that make effluent worst, so the industries should treat their effluent before final disposal into drain.

\section{References}

Abdel-Saheb, I., Schwab, A.P., Banks, M.K., Hetrick, B.A. 1994. Chemical characterization of heavy metal contaminated soils in South-East Kensas. Water, Air and Soil Pollution, 78: 73-82.

Antonious, F.G., San, O.D., Jason, M.U., John, C.S. 2011. Heavy metal uptake in plant parts of sweetpotato grown in soil fertilized with municipal sewage sludge. International Journal of Geology, 5: 14-20.

AOAC, 2005. Official Method of Analysis, $18^{\text {th }}$ edition, AOAC International, Gaithersburg, MD., USA.

APHA, 2005. Standard Methods for the Examination of Water and Wastewater, $21^{\text {st }}$ edition, American Public Health Water Works Association/Water Environmental Federation, Washington, DC., USA.

Bashir, F., Shafiq, T., Kashmiri, M.A., Tariq, M. 2007. Contents and fractionation of heavy metals in soils irrigated with sewage effluents. Journal of the Chemical Society of Pakistan, 29: 94-97.

Bigdeli, M., Seilsepour, M. 2008. Investigation of metals accumulation in some vegetables irrigated with wastewater in Shahre Rey- Iran and toxicological implications. American-Eurasian Journal of Agricultural and Environmental Sciences, 4: 86-92.

Boon, D.Y., Soltanpur, P.N. 1992. Lead, cadmium and zinc contamination of Aspen Garden soils and vegetation. Journal of Environmental Quality, 21: 82-86.

Day, A.D., Tucker, T.C. 1977. Effect of treated municipal wastewater on growth, fibre, protein and amino acid content of sorghum grain. Journal of Environmental Quality, 6: 325-327.

Day, A.D., Taher, F.A., Katterman, F.R.H. 1975. Influence of treated municipal wastewater on growth, fibre, acid soluble nucleotides, protein and amino acid contents in wheat grain. Journal of Environmental Quality, 4: 167-172.

Din, S., Salariya, A. M., Hafeez, J., Yasin, M., Ashraf, M. 2001. Heavy metal contents of some vegetables collected from fields irrigated with polluted water. Pakistan Journal of Scientific Research, 53: 103107.

Feigin, A., Ravina, I., Shalhevet, J. 1991. Irrigation with Treated Sewage Effluent Management for Environmental Protection, 244 pp., Heidelberg, Germany.

Gupta, A.P., Antil, R.S., Singh, A. 1986. Composition of some sewer water and their effect on soil properties. In: Proceedings of National Seminar on Environmental Pollution Control and Monitoring, pp. 419-425, Chundigarh Punjan, India.

Huamain, C. Chungrong, T., Cong, T., Yongguan, Z. 
1999. Heavy metal pollution in soils in China, Status and Countermeasures. Ambio, 28: 130-134.

Jaffar, M., Saleem, M. 1987. Concentration of selected toxic trace metals in some vegetable and fruits of local origin. Pakistan Journal of Agricultural Sciences, 24: 140-145.

Kamel, Z.A., Nada, A.A. 2008. Performance of wastewater treatment plant in Jordan and sustainability for reuse. African Journal of Biotechnology, 7: 2621-2629.

Kipnis, T., Feigin, A., Dovraf, A., Levanon, D. 1979. Ecological and agricultural aspects of nitrogen balance in perennial pasture irrigated with municipal effluents. Progress in Water Technology, 11: 127-138.

Liang, J., Chen, C., Song, X., Han, Y., Liang, Z. 2011. Assessment of heavy metal pollution in soil and plant from dunhua sewage irrigation area. International Journal of Electrochemical Sciences, 6: 5314-5324.

Magdaleno, H.F., Villa, O.R.M., Saenz, E.M., Carmen, M.D., Bolaos. O., Olivas, A.L.B. 2011. Heavy metal in agricultural soils and irrigation with wastewater of Mixquiahuala, Hidalgo, Maxico. African Journal of Agricultural Research, 6: 5505-5511.

Misra, S.G., Srivastava, C.P. 1989. Environmental issues and programmes. In: How Safe is Sewage Irrigation, I. Mohan (ed.), 156 pp., New World Environment Series, ASHISH Publishing House, New Dehli, India.

Murtaza, M., Gafoor, A., Qadir, M., Rashid, M.K. 2003. Accumulation and Bioavallability of $\mathrm{Cd}, \mathrm{Co}$ and $\mathrm{Mn}$ in soils and vegetables irrigated with city effluent, Faisalabad, Pakistan. Pakistan Journal of Agricultural Sciences, 40: 18-24.

Nolan, A.L., Lombi, E., McLaughlin, M.J. 2003. Metal bioaccumulation and toxicity in soils-why bother with speciation. Australian Journal of Chemistry, 56: 7791.

Overman, A.R., Evans, L.E. 1978. Effluent irrigation of sorghum sudan grass and kenaf. Journal of the Environmental Engineering Division, 104: 10611066.

PEPA, 1997. National Environmental Quality Standard for Municipal and Liquid Industrial Effluent, Pakistan Environmental Protection Act, The
Gazzette of Pakistan, 6 pp., Islamabad, Pakistan.

Pescod, M.B. 1992. Wastewater Treatment and Use in Agriculture, FAO Irrigation and Drainage Paper no. 47, Food and Agricultural Organization of the United Nations, Rome, Italy.

Quinn, B.F. 1979. Surface irrigation with sewage effluent in Newzeland, a case study. Progress in Water Technology, 11: 103-126.

Rahmani, R.H. 2007. Use of Industrial and municipal effluent water in Esfahan Province - Iran. Scientific Research and Essay, 2: 84-88.

Rai, P.K., Tripathi, B.D. 2008. Heavy metals in industrial wastewater, soil and vegetables in Lotha village, India. Toxicological \& Environmental Chemistry, 90: 247-257.

Richards, L.A. 1954. Diagnostic and Improvement of Saline and Alkali Soils, US Salinity Laboratory Staff, Handbook No. 60, USDA, Washington, DC., USA.

Rowell, D.L. 1994. Soil Science: Method and Applications, Longman Group Limited, Longman Scientific and Technical, Harlow, UK,

Sinha, S., Pandey, K., Gupta, A.K., Bhatt, K. 2005. Accumulation of metals in vegetables and crops grown in the area irrigated with river water. Bulletin of Environmental Contamination and Toxicology, 74: 210-218.

Tessier, A., Campbell, P.G.C., Bisson, M. 1979. Sequential extraction procedure for the speciation of particulate trace metals. Analytical Chemistry, 51: 844-851.

Van der Hoek, W., Hassan, M.U., Ensink, J.H.J., Feenstra, S., Richard-Sally, L., Munir, S., Aslam, R., Ali, N., Hussain, R., Matsuno, Y. 2002. Urban Wastewater: A Valuable Resource for Agriculture Research Report no. 63, A Case Study from Haroonabad, Pakistan. International Water Management Institute (IWMI), Colombo, Sri Lanka.

Wallace, G.A., Wallace, A. 1994. Lead and other potentially toxic heavy metals in soil. Communications in Soil Science and Plant Analysis., 25: 137-141.

WHO, 1996. Guidelines for Drinking Water Quality, Health Criteria and Other Supporting Information, vol. 2, 973 pp., $2^{\text {nd }}$ edition, World Health Organization, Geneva, Switzerland. 